\title{
INWAZJA JAPOŃSKA \\ NA PÓŁWYSEP KOREAŃSKI W LATACH 1592-1598 \\ A ROSZCZENIA RESTYTUCYJNE KOREAŃCZYKÓW
}

\section{Wprowadzenie}

Półwysep Koreański od III w. n.e. stanowił dla Japończyków główny szlak prowadzący do rozwoju kulturalnego, religijnego, militarnego i technologicznego. Cieśnina Koreańska była miejscem licznych wymian handlowych oraz migracji ludności ${ }^{1}$. Wieloletnie pokojowe, poprawne relacje między Cesarstwem Japonii a królestwem Joseon zostały przerwane przez nagła inwazję Japończyków na Półwysep Koreański w latach 1592-1598. Ten akt agresji w historiografii nazywany jest również wojną siedmioletnią lub wojną $\operatorname{Imjin}^{2}$ i uważa się go za jeden z najistotniejszych konfliktów zbrojnych w historii państwa koreańskiego. Wpływ wojny na stan kraju był katastrofalny, ponieważ - oprócz śmierci niezliczonych ofiar, niemalże całkowitego zrujnowania miast i pól uprawnych - skradziono bądź zniszczono cenne i niepowtarzalne dobra kultury, w tym zabytkowe budynki, dokumenty historyczne, księgi, artefakty czy dzieła sztuki. Powrót do dawnej świetności po wyniszczającej wojnie zajął mieszkańcom półwyspu wiele stuleci³

W tym kontekście nasuwa się pytanie: czy mieszkańcy Korei Południowej i Korei Północnej mają prawo domagać się zwrotu zagrabionych dóbr kultury po 423 latach od zakończenia wojny Imjin. Czy istnieje podstawa prawna dla ich roszczeń, czy jedynym rozwiązaniem jest odwoływanie się do moralności, poczucia sprawiedliwości i uczciwości współczesnych Japończyków? Nie mniej istotne jest też uwzględnienie sytuacji politycznej między państwami i możliwe pogorszenie lub poprawienie się napiętych od lat relacji na tle żądań restytucyjnych.

ORCID: 0000-0002-3246-3937, DOI: 10.4467/23538724GS.21.015.14847

1 O. Pietrzyk, Polityka Japonii wobec państw Pótwyspu Koreańskiego [w:] Polityka zagraniczna Japonii, red. A.W. Ziętek, K. Żakowski, O. Pietrzyk, Lublin 2018, s. 184.

2 J. Kim, Museums and cultural heritage: to examine the loss of cultural heritage during colonial and military occupations with special reference to the Japanese occupation of Korea, and the possibilities for return and restitution, nieopublikowana rozprawa doktorska, City, University of London, London 2018, s. 12.

3 M. Pal, The Japanese invasions of Korea: who was the real winner of the Imjin war?, Genève 2020, s. 7. 


\section{Przebieg wojny}

Inwazję na Półwysep Koreański pod koniec XVI w. zainicjowała jedna z najważniejszych postaci w historii Japonii - Toyotomi Hideyoshi. Jest on prawdopodobnie jedynym przypadkiem w dziejach średniowiecznej Japonii, gdy do szczytu władzy doszła osoba spoza arystokracji. Hideyoshi, pochodzacy z rodziny drobnych właścicieli dworskich ${ }^{4}$, miał bardzo silną osobowość, słynął z okrucieństwa, wzbudzania strachu oraz żądania bezwzględnego posłuszeństwa. Był człowiekiem nienasyconym władza. Zarazem jednak był twórca jednolitego i ściśle scentralizowanego państwa, które doprowadził do świetności po okresie wyniszczających wojen domowych.

Można wskazać kilka czynników, które doprowadziły do rozpoczęcia natarcia przez Hideyoshiego. Podboje zamorskie miały skierować uwage posiadaczy ziemskich (daimyō) poza wyspy, a dzięki temu uciszyć liczne głosy sprzeciwiające się rządom surowego przywódcy ${ }^{5}$. Po wygranej istniałaby możliwość rozdzielenia przejętych terytoriów między poszczególnych panów feudalnych, co prawdopodobnie ograniczyłoby opozycję wobec polityki wewnętrznej Hideyoshiego. Innym powodem wszczęcia wojny była chęć obwołania Japonii hegemonem w regionie Azji Wschodniej, tym samym Korea miałaby zostać bazą dla dalszej ekspansji na północ. Dzięki podbojowi Korei i Chin Hideyoshi zamierzał stworzyć bezkresne imperium, a sam miał zdobyć liczne zaszczyty i tytuły. Badacze wskazują również, że za decyzją o ataku na półwysep mogło stać ukaranie jej mieszkańców za brak ustępliwości co do międzypaństwowych rokowań handlowych ${ }^{6}$.

Wiosną 1592 r. pierwszy oddział z trzystutysięcznej armii ${ }^{7}$ dotarł z wyspy $\mathrm{Cu}-$ szima do wybrzeża miasta Pusan. Strona japońska jednak nie natrafiła na żaden zorganizowany opór ani na lądzie, ani na morzu. Ignorancja ze strony dworu królewskiego wobec potęgi militarnej Japonii była jedną z głównych przyczyn szybkiej i skutecznej ekspansji wojsk wroga. Mimo że po objęciu przywództwa politycznego przez Hideyoshiego w 1585 r. Cesarstwo Japonii stało się najsilniejszym i najniebezpieczniejszym państwem w regionie Azji Wschodniej, władze królestwa Joseon nie zdecydowały się na rozbudowę armii czy scentralizowaną obronę rozległej linii brzegowej ${ }^{8}$. Co więcej, panujący w tym okresie koreański król Seonjo zlekceważył wystosowane wcześniej żądanie, by wyraził zgodę na przemarsz wojsk japońskich ku granicy z Chinami, rządzonej wówczas przez dynastię Ming. Brak natychmiastowej reakcji dworu na wieść o ataku oraz niewydanie konkretnych rozkazów do

4 A. Iskenderow, Toyotomi Hideyoshi, tłum. E. Szulc, Warszawa 1991, s. 5, 22.

Ibidem, s. 263.

Ibidem, s. 262, 270.

Ibidem, s. 274.

8 M. Jacoby, Korea Poludniowa. Republika Żywiołów, Warszawa 2018, s. 148. 
mobilizacji armii i floty zdecydowanie przyczyniły się do utorowania przeciwnikowi drogi do stolicy ${ }^{9}$.

Król wraz z członkami dworu zbiegli na północ kraju tuż przed dotarciem Japończyków do Seulu. Rozgoryczeni tym wydarzeniem mieszkańcy spalili wówczas budynki rządowe i pałace. Głównodowodzący wojsk japońskich w Korei, Ukita Hideie, zajął stolicę bez przeszkód i założył tam sztab dowodzenia. Nową siedzibą władz królestwa stało się zaś miasto Pjongjang, które jednak zostało zdobyte przez wroga już w czerwcu 1592 r. Kolejnym miejscem ucieczki przywódców Korei stało się Uiju. Hideie był wówczas przeświadczony, że Koreańczycy zostali pokonani i za kolejny cel ekspansji obrał Chiny. Obawiał się jednak podjąć tak ryzykowną decyzję samodzielnie, bez wyraźnej zgody Hideyoshiego, który nigdy nie pojawił się osobiście na półwyspie w trakcie wojny ${ }^{10}$.

Wojska koreańskie zostały pozostawione zupełnie bez nadzoru, rozkazów i odgórnego dowództwa. Po serii porażek udało się wszakże zmobilizować siły oraz zrealizować szereg operacji wojskowych. Nie można pominać wpływu, jaki na przebieg konfliktu miała koreańska partyzantka, nazywana Armią Sprawiedliwości. Ten zryw ludności stał się potężną siłą militarna, która poderwała do walki rozczarowany władzą królewską i nastawiony antyjapońsko naród. Zajmowała się przede wszystkim obroną obleganych miast, napadami na garnizony wroga oraz współdziałaniem z regularną armią ${ }^{11}$.

Pod koniec 1592 r. armia japońska poniosła pierwszą większą porażkę, gdy połączone siły Chin i Korei odbiły Pjongjang. W tym okresie widoczne stały się wśród żołnierzy i dowództwa japońskiego oznaki zmęczenia i zniechęcenia wojną. Mimo opanowania ponad połowy państwa utrapieniem stały się epidemie, dezercje, upadek dyscypliny wojskowej, a także kończące się zasoby. W tej sytuacji Japonia zdecydowała się na rozmowy pokojowe ze stroną chińską, podczas których zignorowano interesy Korei i zlekceważono obecność jej wysłanników. Gdy w czerwcu 1593 r. w Nagoi pojawili się chińscy posłowie, przywódca Japonii zażądał spełnienia niedorzecznych dla dynastii Ming warunków. Oprócz poślubienia córki cesarza Chin i przebywania na wyspach książąt koreańskich jako zakładników Hideyoshi wymagał również wznowienia stosunków handlowych (w zakresie publicznym i prywatnym) między Japonią a Chinami, przyłączenia do Japonii czterech południowych prowincji królestwa Joseon oraz złożenia przez dwór przysięgi, że nigdy nie podniesie buntu przeciw władzy japońskiej ${ }^{12}$. Strona chińska zaś zaproponowała nadanie Hideyoshiemu tytułu króla (wanga).

\footnotetext{
9 A. Iskenderow, Toyotomi Hideyoshi..., s. 275.

10 Ibidem, s. 354.

11 Ibidem, s. 285.

12 Ibidem, s. 288, 293.
} 
Rokowania przebiegały pomyślnie z prostego powodu. Przedstawiciele Chin i Japonii zmieniali charakter debaty i żądań obu stron tak, aby nie rozgniewać swoich mocodawców ${ }^{13}$. Gdy długo wyczekiwane poselstwo z Chin ponownie pojawiło się w Nagoi w 1597 r., Hideyoshi postanowił zorganizować oficjalną ceremonię nadania mu tytułu króla Chin na podstawie cesarskiego edyktu. W obecności największych osobistości dworskich posłowie chińscy publicznie ogłosili, że Toyotomi Hideyoshi jest wangiem Japonii, wasalem cesarza Chin oraz jest zobowiązany składać coroczną daninę. Oburzony i ośmieszony przywódca postanowił zerwać zawieszenie broni i rozpocząć drugą kampanię militarną na terenie Korei ${ }^{14}$.

Podczas tego etapu wojny największą trudnością dla Japończyków okazała się siła koreańskiej floty. Początkowo armada koreańska, mimo imponującego wyposażenia i liczby okrętów, była całkowicie nieskoordynowana i pozbawiona jednolitego zwierzchnictwa. Jednakże w drugiej fazie wojny odznaczyła się licznymi sukcesami dzięki przejęciu dowództwa przez największego bohatera narodowego Korei, Yi Sun-Sina ${ }^{15}$. Admirał zapisał się w historii jako znakomity strateg, który z niemalże każdej bitwy wychodził zwycięsko. Statki marynarki japońskiej (głównie o charakterze handlowym) nie mogły dorównać słynnym opancerzonym okrętom żółwiom (geobukseon) komenderowanym przez admirała.

W grudniu $1598 \mathrm{r}$. doszło do ostatniego starcia podczas wojny Imjin. W bitwie morskiej pod Noryang zmobilizowano niemalże 5 tys. okrętów japońskich, jednak sprzymierzone siły Korei i Chiny okazały się nie do pokonania. Wynik tej potyczki był drastyczny w skutkach, gdyż zniszczeniu uległa znaczna część japońskiej floty, a śmierć poniosło ponad 10 tys. osób, w tym legendarny admirał Yi Sun-Sin.

Punktem kulminacyjnym zakończenia inwazji na półwysep okazała się wiadomość o śmierci Toyotomiego Hideyoshiego we wrześniu 1598 r. Armia była wówczas rozbita, przez co sytuacja na froncie stawała się bardzo niekorzystna dla strony japońskiej. Aby ocalić pozostałości wojsk, zdecydowano się na zawarcie rozejmu z Chinami. Obie strony konfliktu nie mogły się porozumieć co do warunków zawieszenia broni, postanowiono więc przerwać działania wojenne, pomijając oficjalne zawarcie pokoju $\mathrm{u}^{16}$.

Inwazję na Półwysep Koreański pod koniec XVI w. można określić jako błąd w polityce zagranicznej cesarstwa Japonii. Od tego momentu uważano je za agresora i zaborcę atakującego sąsiadów mimo braku prowokacji ${ }^{17}$. Decyzja o inwazji na Koreę była pozbawiona realnych perspektyw, a skutkowała jedynie ogromnymi ofiarami, ubóstwem i dewastacja. Prawdopodobnie stanowiła jedną z przyczyn ,zamknięcia się Japonii" po dojściu do władzy rodu Tokugawów.

13 Ibidem, s. 291.

14 Ibidem, s. 295-296.

15 Ibidem, s. 282.

16 Ibidem, s. 304-305.

17 Ibidem, s. 270. 


\section{Skutki wojny Imjin dla Korei i Japonii w aspekcie kulturalnym}

Hideyoshi, mimo że był dyletantem w dziedzinie sztuki, stał się odpowiedzialny za odbudowę wielu pałaców, rezydencji, świątyń i chramów ${ }^{18}$. Chętnie otaczał się sztuką, dlatego przejęcie wysokiej jakości dóbr kultury z Korei do Japonii okazało się kluczowe. Przywódca utworzył sześć wyspecjalizowanych oddziałów zajmujących się wyłącznie przejmowaniem książek, dokumentów, wartościowych materiałów, obrazów oraz porywaniem rzemieślników i artystów na wyspy ${ }^{19}$.

Trudno oszacować, ile konkretnie obiektów wywieziono podczas inwazji na pó1wysep w XVI w. Wiadomo, że Japonia zwróciła Korei 1321 dóbr kultury powstałych w okresie Joseon (1392-1910), jednakże w japońskich muzeach, uniwersytetach, bibliotekach oraz prywatnych kolekcjach nadal pozostaje wiele dzieł sztuki koreańskiej. Jako przykład można wskazać powstały w 1447 r. obraz Mongyudowondo, obecnie znajdujący się w Bibliotece Uniwersytetu Tenri w prefekturze Nara ${ }^{20}$. Mimo że dzieło to jest uważane za jedno z najważniejszych obrazów sztuki koreańskiej, władze uniwersytetu nie przystały na propozycję restytucji ${ }^{21}$.

Strona koreańska twierdzi, że podczas wojny Imjin zagrabiono niezliczone dzieła sztuki z okresu Goryeo (918-1392), słynnego z ceramiki, świętych ksiąg (Tripitaka Koreana) oraz pierwszej ruchomej czcionki22. Pierwsze czcionki powstały w 1234 r., czyli ponad 200 lat przed wynalazkiem Gutenberga. Zestawy składały się z kilku tysięcy elementów z drewna, brązu czy mosiądzu, a każdy przedstawiał jeden znak chiński ${ }^{23}$. Z czasem Japończycy, wykorzystując przywiezione z Korei zestawy ruchomych czcionek, wytworzyli własne drewniane wersje, dzięki czemu udało im się rozpowszechnić druk na szerszą skalę ${ }^{24}$. Obecnie ok. 6 tys. wówczas zagrabionych czcionek umieszczono w Bibliotece Uniwersytetu w Tokyo. Należy też wspomnieć, że w świątyniach szintoistycznych na terenie Japonii znajduje się nadal ponad 50 dzwonów koreańskiej produkcji ${ }^{25}$, ponadto jedna z kamiennych latarni stworzonych w Korei jest umiejscowiona w świątyni buddyjskiej Daitokuji w Kioto, z kolei fragment bramy Sungnyemun (najstarszej drewnianej budowli w Seulu powstałej w XIV w.) obecnie pełni funkcję świątynnej ozdoby ogrodowej.

18 C. Totman, Historia Japonii, tłum. J. Hunia, Kraków 2009, s. 274.

19 M. Koo, Repatriation of Korean cultural property looted by Japan - can a sincere apology resolve the centuries-old Korea/Japan disputes?, „Cardozo Journal of Conflict Resolution” 2015, vol. 16, no. 2, s. 628.

20 G. Scott, Spoliation, Cultural Property, and Japan, „University of Pennsylvania Journal of International Economic Law" 2008, vol. 29, no. 4, s. 857.

${ }^{21}$ K. Itoi, Korea: A tussle over treasures, 20.02.2005, https://www.newsweek.com/korea-tussle-over-treasures-122061 (dostęp: 11.06.2021).

22 G. Scott, Spoliation..., s. 825.

23 J. Rurarz, Historia Korei, Warszawa 2014, s. 349.

$24 \mathrm{~J}$. Kim, Museums and cultural heritage..., s. 41.

25 Ibidem, s. 35. 
Koreańczycy utracili liczne elementy dziedzictwa kultury nie tylko poprzez wywóz na wyspy, ale również w wyniku celowych zniszczeń i dewastacji. Jeden z największych klasztorów buddyjskich na Półwyspie Koreańskim, Hwaeomsa, został doszczętnie spalony, zaś w maju 1592 r. doszło do zburzenia świątyni buddyjskiej Jongmyo, która służyła uczczeniu pamięci zmarłych władców ${ }^{26}$. Japońskie wojska spaliły także bibliotekę, główną świątynię oraz salę wykładową najważniejszej instytucji naukowej w ówczesnej Korei - Sungkyunkwan. Przypuszcza się, że część ksiąg z tego kompleksu zabrano do Kioto ${ }^{27}$. Dewastacji uległy również pałac Changgyeonggung, a także Gyeongbokgung wraz z jego główną bramą Gwanghwamun ${ }^{28}$. Wycofujący się z Seulu Japończycy w 1598 r. zburzyli dawną stolicę starożytnego państwa Silla - Gyeongju. Wówczas zrujnowano niezliczoną liczbę świątyń, zabytków architektury, pamiątek historycznych i kulturowych ${ }^{29}$.

Oprócz strat materialnych Korea została pozbawiona też wielu wybitnych artystów i rzemieślników. Podczas inwazji przywieziono do Japonii ok. 100 tys. jeńców, a wśród nich liczną grupę malarzy, kowali, garncarzy, cieśli, badaczy, uczonych czy medyków ${ }^{30}$. Jeńcy przyczynili się do powstania w Japonii nowych technik tworzenia ceramiki, garncarstwa i porcelany ${ }^{31}$. Pracując pod kierownictwem Sen no Rikyu, mistrza ceremonii przyrządzania zielonej herbaty, dwaj pojmani Koreańczycy wynaleźli nowy rodzaj ceramiki - raku-yaki ${ }^{32}$. Do dziś porcelana z Kiushu jest znana na całym świecie, a jej twórcami byli także jeńcy wojenni ${ }^{33}$. Koreańczycy wprowadzili na wyspy swój rodzimy wariant celadonów, czyli ceramiki pokrytej grubym, oliwkowozielonym czy niebieskim szkliwem ${ }^{34}$. Charakteryzują się one prostymi i abstrakcyjnymi zdobieniami, zaś tlenek żelaza nadaje im czerwone zabarwienie ${ }^{35}$. Jeden z rzemieślników, Yi Sam-pyeong w 1616 r. odkrył unikalną glinę, dzięki której doszło do rozpowszechnienia się produkcji porcelany Arita. Z uwagi na liczbę sprowadzonych na wyspy twórców ceramiki wojna Imjin jest też określana jako wojna ceramiczna (yakimono sensōo) ${ }^{36}$.

\footnotetext{
26 Ibidem, s. 26.

27 Ibidem, s. 30, 32.

28 Ibidem, s. 29.

29 A. Iskenderow, Toyotomi Hideyoshi..., s. 303.

$30 \mathrm{~J}$. Kim, Museums and cultural heritage..., s. 24.

31 M. Pal, The Japanese invasions..., s. 10.

32 G. Scott, Spoliation..., s. 835.

33 M. Booth, Japonia, Chiny $i$ Korea. O ludziach sketóconych na śmierć $i$ jycie, tłum. B. Gutowska-Nowak, Kraków 2021, s. 143.

34 M. Jacoby, Korea Południowa..., s. 149.

35 B. Bizalion, Japonia [w:] Wielkie kultury świata. Islam, Chiny, Japonia, kultury andyjskie, red. M. Kardasz, tłum. P. Lewiński, Warszawa 1998, s. 409.

$36 \mathrm{~J}$. Kim, Museums and cultural heritage..., s. 24.
} 
Argumenty strony koreańskiej i kontrargumenty strony japońskiej w sprawie restytucji zagrabionych pod koniec XVI w. dóbr kultury

Kluczowe dla zrozumienia żądań strony koreańskiej dotyczących zwrotu utraconych dóbr kultury jest zdefiniowanie dwóch pojęć. Pierwszy z nich to element dziedzictwa, przez który należy rozumieć „,konkretny fenomen z zakresu sztuki, architektury, muzyki, literatury, religii, kultury materialnej, obrzędowości czy innych dziedzin ludzkiej aktywności”' ${ }^{37}$. Definicja ta obejmuje przedmioty mające pewną wartość historyczną, artystyczną czy naukową i kształtujące tożsamość określonej grupy społecznej, dzięki czemu istotne jest przekazywanie ich następnym pokoleniom. Drugie pojęcie to tradycja w stosunku do sztuki, którą można określić jako „zespół konkretnych dokonań przeszłości czy wytworów traktowanych jako wzorcowe rozwiązania artystyczno-ideowe, albo jako opinie i sposoby zachowań, które znalazły wyraz w postaci norm traktowanych jako obowiązujące zasady tworzenia i oceny dzieł"38.

Wojna spowodowała wieloletni zastój państwa koreańskiego w rozwoju cywilizacyjnym, natomiast dla Japonii był to korzystny okres rozkwitu sztuki ${ }^{39}$. W wyniku konfliktu naród koreański został pozbawiony możliwości kultywowania dziedzictwa i tradycji. Utracenie przedmiotów stanowiących podstawę narodowej tożsamości utrudnia poznawanie swojej spuścizny oraz odnalezienie własnego miejsca w teraźniejszości ${ }^{40}$. Odzyskanie zagrabionych dóbr kultury pozwala skuteczniej zapobiegać traumie oraz tworzyć nowe dziedzictwo. Dzięki temu można również dokładniej poznać proces dziedziczenia kultury. Istotne jest pielegnowanie tradycji i podtrzymywanie tego, co dawne ${ }^{41}$. Badania nad własnymi dobrami kultury wzbogacają naród, inspirują twórców oraz pobudzają chęć do kształcenia się. Dobra kultury mogą być wykorzystywane do promowania twórczości artystycznej i nauki za pomocą instrumentów dydaktycznych i wychowawczych. Naród pozbawiony sztuki staje się kulturowo ubogi ${ }^{42}$, a zagrabienie dobra kultury z oryginalnego historycznego miejsca, z którego pochodzi, może spowodować obniżenie jego wartości. Dlatego ochrona dziedzictwa kultury jest istotna dla kształtowania nowoczesnego, lecz świadomego swej historii społeczeństwa ${ }^{43}$.

Z roszczeniami strony koreańskiej ściśle wiąże się również pojęcie restytucji, przez które można rozumieć zwrot mienia bezprawnie zagrabionego oraz naprawę

37 A. Szczerski, \#dziedzৃictwo [w:] \#dzৃiedzৃictwo i odpowiedź, w sžtuce wspótczesnej, red. L. Murzyn, R. Solewski, S. Stankiewicz, B. Stano, tłum. R. Kusek, M. Czuchra, Kraków 2018, s. 19.

38 G. Sztabiński, Historia jako obietnica [w:] \#dziedzictwo i odpowiedź..., s. 102.

39 J. Rurarz, Historia Korei..., s. 360.

40 A. Szczerski, \#driedzictwo..., s. 20.

41 G. Sztabiński, Historia jako obietnica..., s. 107.

42 J. Merryman, Thinking about the Elgin Marbles, „Michigan Law Review” 1985, vol. 83, no. 1880, s. 1913.

43 P. Żarkowski, Ocbrona dóbr kultury w czasie wojny w śnietle prawa międrynarodowego, „Krakowskie Studia Międzynarodowe" 2016, t. 13, nr 3, s. 161. 
wyrządzonych szkód. W związku ze sprzeniewierzeniem dóbr kultury w trakcie konfliktu zbrojnego ma miejsce pozbawienie posiadania pierwotnego właściciela i przemieszczenie danego obiektu ${ }^{44}$. Konieczne dla restytucji jest dokładne wskazanie, co zostało utracone (a jeżeli zwrot oryginału nie jest możliwy, to należy rozważyć przekazanie odpowiednika ${ }^{45}$ ) i gdzie obecnie się znajduje. Nie można dokonać restytucji dóbr kultury już nieistniejących czy takich, co do których zwrot jest niewykonalny ${ }^{46}$.

Wydaje się, że korzystnym rozwiązaniem dla Korei mogłoby być zastosowanie regulacji zawartych w Konwencji o ochronie dóbr kulturalnych w razie konfliktu zbrojnego, podpisanej w Hadze 14 maja 1954 r. (Dz. U. z 1957 r. Nr 46, poz. 212). Był to wówczas przełomowy akt prawny, traktujący dobra kultury jako istotne dla całej społeczności międzynarodowej, a nie tylko z perspektywy konkretnego państwa. Wskazano, że dla ochrony dziedzictwa kultury mało znaczace jest pochodzenie, obecne położenie czy osoba właściciela dobra. Podstawowym celem sporządzenia tego dokumentu była ochrona dóbr kultury w czasie pokoju, natomiast w czasie wojny miał on określać czynności konieczne do podjęcia przez siły zbrojne i administrację publiczną w celu zabezpieczenia przed ewentualnymi szkodami ${ }^{47}$. Jednakże w prawie międzynarodowym do momentu wprowadzenia pierwszych kodyfikacji dotyczących ochrony dóbr kultury na początku XX w. istniało prawo wojny jako komponent suwerenności państwa (ius ad bellum) ${ }^{48}$ oraz prawo łupu (ius praedae). Strona zwycięska miała więc prawo zaatakować zbrojnie w przypadku sporu międzynarodowego, a także wzbogacić się i czerpać korzyści ekonomiczne kosztem pokonanego. Wyżej wspomniana konwencja haska była zaś pierwszą umowa międzynarodową w pełni wyłączająca możliwość stosowania ius praedae ${ }^{49}$. Jako że prawo nie działa wstecz, w czasie wojny Imjin, kilka stuleci przed wejściem w życie konwencji, doszło do legalnego nabycia koreańskich dóbr kultury przez Japończy$k_{\text {ów }}{ }^{5}$. W związku z tym strona japońska może wskazać w odpowiedzi na roszczenia strony przeciwnej zarzut z prawa własności, ponieważ zrabowane pod koniec XVI w. obiekty są od tego czasu w ich legalnym posiadaniu.

Jak już wspomniano, brakuje narzędzi prawnych na tle prawa międzynarodowego mogących zmusić państwo japońskie do dobrowolnego oddania koreańskich

${ }^{44}$ K. Zeidler, Restitution of Cultural Property: Hard Case, Theory of Argumentation, Philosophy of Law, Gdańsk - Warsaw 2016, s. 26, 30.

45 Ibidem, s. 27, 28.

46 Ibidem, s. 47.

47 P. Żarkowski, Ochrona dóbr kultury..., s. 164, 166.

48 J. Zajadło, K. Zeidler, Prawna ochrona zabytków na wypadek wojny [w:] K. Zeidler, Zabytki. Prawo ipraktyka, Gdańsk - Warszawa 2017, s. 321.

49 K. Zeidler, Czy iure praedae nadal istnieje? [w:] idem, Zabytki. Prawo..., s. 392, 394-395.

50 A. Yupsanis, Cultural Property Aspects in International Law: The Case of the (Still) Inadequate Safeguarding of Indigenous Peoples' (Tangible) Cultural Heritage, „Netherlands International Law Review” 2011, vol. 58, no. 3, s. 355. 
dóbr kultury przejętych w czasie wojny siedmioletniej. Inną droga jest odwołanie się do zadośćuczynienia naruszonym zasadom moralnym i żądanie przywrócenia stanu poprzedniego. Żądania należałoby raczej oprzeć na pojęciach dobrowolnego ofiarowania niż pojęciach zwrotu ${ }^{51}$.

Należy jednak zwrócić uwagę również na pojęcie bajronizmu, które stanowi podstawę roszczeń koreańskich. Bajronizm wspiera roszczenia strony pokrzywdzonej, silnie sprzeciwiając się wszelkim próbom wzbogacenia się cudzym kosztem. Mimo legalności na tle prawa międzynarodowego niezaprzeczalny pozostaje fakt, że zrabowane przez Japonię dobra kultury były stworzone w Korei, przez Koreańczyków i dla Koreańczyków. Takie rozumowanie można określić argumentem kulturalnego nacjonalizmu ${ }^{52}$ czy argumentu $\mathrm{z}$ pochodzenia terytorialnego, za pomoca którego domaga się zwrotu zagrabionych dóbr kultury do miejsca ich stworzenia bądź miejsca przebywania członków tego samego narodu co twórca.

Argument z nacjonalizmu kulturowego może być wszakże wykorzystany też przez stronę japońską. Przywłaszczone pod koniec XVI w. dobra kultury są obecnie częścią japońskiej kultury i pomogły ją zdefiniować. Należy przy tym zaznaczyć, że japońskie prawo zezwala na rejestrowanie w spisie zabytków dóbr kultury stworzonych nie tylko w Japonii, lecz także w Chinach czy Korei oraz nadanie części z nich statusu narodowego dziedzictwa, jeżeli mają wystarczające znaczenie dla kultury ${ }^{53}$.

Nie można zaprzeczyć, że Japończycy faktycznie podejmują wysiłki zmierzające do oddania dóbr kultury zarówno na żądanie Koreańczyków, jak i dobrowolnie ${ }^{54}$. Jednym z większych sukcesów na tle poprawy relacji między państwami w tym kontekście było zwrócenie w 2005 r. monumentu Bukgwandaecheopbi wzniesionego w 1707 r. na cześć mieszkańców prowincji Hamgyong, którzy odnieśli serię zwycięstw nad najeźdźcami w latach 1592-1594.

\section{Podsumowanie}

Oba państwa wykorzystują szesnastowieczny konflikt i jego skutki do budowania własnej tożsamości narodowej. Zarówno Japonia, jak i Korea gloryfikują własnych bohaterów narodowych i są dumne z odniesionych zwycięstw. Z powodu zaszłości historycznych ich relacje są niezwykle zawiłe i charakteryzują się brakiem zaufania, a niekiedy nawet niechęcią ${ }^{55}$. Częstymi przedmiotami sporu są szintoistyczna świątynia Yasukuni w Tokio, w której oddaje się cześć nie tylko poległym żołnierzom, lecz

\footnotetext{
51 J. Kim, Museums and cultural heritage..., s. 154.

52 J. Merryman, Thinking about the Elgin Marbles..., s. 1905, 1911-1912.

53 Wypowiedź H. Washizuka, transkrypcja z wydarzenia „Cultural Property Forum: The Export Policies of China, Korea, and Japan”, Japan Society, New York, 9.04.2003, s. 8.

54 G. Scott, Spoliation... s. 886.

55 O. Pietrzyk, Polityka Japonii..., s. 186.
} 
także zbrodniarzom wojennym z czasów II wojny światowej, oraz kopiec Mimizuka w Kioto, gdzie znajdują się nosy i uszy ok. 100 tys. Koreańczyków, zabrane do Japonii jako trofea wojenne w czasie wojny w latach 1592-1598 ${ }^{56}$. Korea Południowa jest dla Japonii jednym z najbliższych partnerów politycznych, gospodarczych i ekonomicznych, a nierozliczone i niewyjaśnione sprawy z przeszłości odsuwają od siebie obu sojuszników ${ }^{57}$. Przepaść, która powstała między Japonią a Koreą Południową, nie sprzyja rozwojowi gospodarczemu i z pewnościa zostanie wykorzystana przez Chiny czy Koreę Północną w celu uzyskania hegemonii w regionie Azji Wschodniej.

Restytucja może stać się prawnym rozwiązaniem dla trudnych relacji japońsko-koreańskich, co więcej - stanowi też wskazówkę moralną, emocjonalną i polityczną do rozstrzygania sporów ${ }^{58}$. Skuteczne negocjacje i działania dyplomatyczne mogłyby doprowadzić do porozumienia i zadośćuczynienia propozycjom, które będą akceptowalne dla obu stron. Dzięki temu relacje między oboma państwami ulegną normalizacji, a prawdopodobnie nawet wzmocnieniu. Jednakże osiagnięcie tego konsensusu może być trudne. Hwang Pyung-Woo z Korea Cultural Heritage Policy Research Institute wskazuje, że najlepszym rozwiązaniem jest skupienie się przede wszystkim na pokojowych rozmowach, ale finalnie mających na celu zwrot jak największej liczby obiektów ${ }^{59}$. Natomiast profesor sztuki z Tokio, Yoko Hayashi, utrzymuje, że właściwiej będzie zwiększyć liczbę wystaw, wspólnych badań naukowych czy też długoterminowych wypożyczeń koreańskich dzieł sztuki, będących w posiadaniu Japonii ${ }^{60}$. Podsumowując, zrezygnowanie ze stanowiska zajętego przez jedną ze stron oraz poświęcenie własnych racji może mieć niebagatelny wpływ na poprawę międzypaństwowych stosunków.

\section{Literatura}

Bizalion B., Japonia [w:] Wielkie kultury śmiata. Islam, Chiny, Japonia, kultury andyjskie, red. M. Kardasz, tłum. P. Lewiński, Warszawa 1998.

Booth M., Japonia, Chiny i Korea. O ludz̧iach sktóconych na śmierć $i$ syccie, tłum. B. Gutowska-Nowak, Kraków 2021.

Glionna J., Recovering South Korea's lost treasures, 5.12.2010, https://www.latimes.com/archives/ la-xpm-2010-dec-05-la-ca-cultural-exchange-korea-20101205-story.html (dostęp: 11.06.2021). Iskenderow A., Toyotomi Hideyoshi, tłum. E. Szulc, Warszawa 1991.

Itoi K., Korea: A tussle over treasures, 20.02.2005, https://www.newsweek.com/korea-tussle-over-treasures-122061 (dostęp: 11.06.2021).

56 G. Scott, Spoliation..., s. 818.

57 O. Pietrzyk, Polityka Japonii..., s. 196.

$58 \mathrm{~J}$. Stepnowska, Asian cultural objects in Europe. Art market expansion and the illicit trafficking of cultural heritage: An outline of legal issues, „Gdańskie Studia Azji Wschodniej” 2017, z. 12, s. 61.

59 J. Glionna, Recovering South Korea's lost treasures, 5.12.2010, https://www.latimes.com/archives/ la-xpm-2010-dec-05-la-ca-cultural-exchange-korea-20101205-story.html (dostęp: 11.06.2021).

${ }^{60}$ K. Itoi, Korea... 
Jacoby M., Korea Południowa. Republika Żywiołón, Warszawa 2018.

Kim J., Museums and cultural heritage: to examine the loss of cultural heritage during colonial and military occupations with special reference to the Japanese occupation of Korea, and the possibilities for return and restitution, nieopublikowana rozprawa doktorska, City, University of London, London 2018.

Koo M., Repatriation of Korean cultural property looted by Japan - can a sincere apology resolve the centuries-old Korea/Japan disputes?, „Cardozo Journal of Conflict Resolution” 2015, vol. 16, no. 2.

Merryman J., Thinking about the Elgin Marbles, „Michigan Law Review” 1985, vol. 83, no. 1880.

Pal M., The Japanese invasions of Korea: who was the real winner of the Imjin war?, Genève 2020.

Pietrzyk O., Polityka Japonii wobec państw Pótwyspu Koreańskiego [w:] Polityka zagraniczna Japonii, red. A.W. Ziętek, K. Żakowski, O. Pietrzyk, Lublin 2018.

Rurarz J., Historia Korei, Warszawa 2014.

Scott G., Spoliation, Cultural Property, and Japan, „University of Pennsylvania Journal of International Economic Law" 2008, vol. 29, no. 4.

Stepnowska J., Asian cultural objects in Europe. Art market expansion and the illicit trafficking of cultural heritage: An outline of legal issues, „Gdańskie Studia Azji Wschodniej” 2017, z. 12.

Szczerski A., \#dziedzictwo [w:] \#dziedzictwo i odpowied乏́ w sztuce wspótczesnej, red. L. Murzyn, R. Solewski, S. Stankiewicz, B. Stano, tłum. R. Kusek, M. Czuchra, Kraków 2018.

Sztabiński G., Historia jako obietnica [w:] \#dziedzictwo i odpowiedźw sztuce wspótczesnej, red. Ł. Murzyn, R. Solewski, S. Stankiewicz, B. Stano, tłum. R. Kusek, M. Czuchra, Kraków 2018.

Totman C., Historia Japonii, tłum. J. Hunia, Kraków 2009.

Washizuka H., transkrypcja z wydarzenia „Cultural Property Forum: The Export Policies of China, Korea, and Japan”, Japan Society, New York, 9.04.2003.

Yupsanis A., Cultural Property Aspects in International Law: The Case of the (Still) Inadequate Safeguarding of Indigenous Peoples' (Tangible) Cultural Heritage, „Netherlands International Law Review” 2011, vol. 58 , no. 3 .

Zajadło J., Zeidler K., Prawna ochrona zabytków na wypadek, wojny [w:] K. Zeidler, Zabytki. Prawo i praktyka, Gdańsk - Warszawa 2017.

Zeidler K., Cay iure praedae nadal istnieje? [w:] idem, Zabytki. Prawo i praktyka, Gdańsk - Warszawa 2017.

Zeidler K., Restitution of Cultural Property: Hard Case, Theory of Argumentation, Philosophy of Law, Gdańsk - Warsaw 2016.

Zeidler K., Zabytki. Prawo i praktyka, Gdańsk - Warszawa 2017.

Żarkowski P., Ocbrona dóbr kultury w czasie wojny w swietle prawa międsynarodowego, „Krakowskie Studia Międzynarodowe" 2016, nr 3.

\section{SUMMARY}

\section{THE JAPANESE INVASION OF THE KOREAN PENINSULA IN 1592-1598 AND KOREAN CLAIMS FOR RESTITUTION}

The article presents a brief history of the Japanese invasion of the Korean Peninsula in the end of the $16^{\text {th }}$ century (also called the Imjin war) as well as it's tragic effects. This conflict brought not only countless victims and desolation of cities and farmlands, but also complete cultural devastation in the Joseon Kingdom. Thousands of Korean cultural goods were demolished or burned down, while others were taken away to Japan and some of them are 
considered to be a part of Japanese cultural heritage. Therefore, it should be answered if Koreans nowadays have any right to demand restitution of these stolen objects. Korean recovery claims are mostly based on byronism and cultural nationalism, considering the lack of legal measures. The interest of the Japanese side to reject restitution of looted goods is secured by ius praedae. In the $16^{\text {th }}$ century, it was a crucial principle of international law allowing one country to invade and plunder another, therefore, the Japanese are not obliged to return any of the appropriated objects. Nevertheless, in consideration of improving tense relations between the two countries, negotiating a settlement reciprocal for both parties concerning restitution claims of the Koreans through diplomatic channels should be undertaken. 